\title{
ANALISIS DAMPAK PARIWISATA KAMPUNG COKLAT DALAM ASPEK EKONOMI DAN SOSIAL MASYARAKAT
}

\author{
Kadeni $^{1)}$, Ninik Srijani ${ }^{2)}$ \\ STKIP PGRI Blitar", ${ }^{1}$, Universitas PGRI Madiunn') \\ denikdk@gmail.com ${ }^{1)}$,ninikikipae@gmail.com ${ }^{2)}$
}

\begin{abstract}
At present the existence of the tourism sector has become a concern of the community so that in various regions new tourist spots have emerged. Similarly, in Blitar, there are also many new tourist sites built, one of which is brown village tourism. With the construction of tourist attractions will have an impact on the economic and social community. This study aims to describe the impact of tourism on the economy and society. The research method used to answer these problems is to use a descriptive qualitative approach. Data obtained using observation and interviews, while data analysis three stages, namely data reduction, data display and verification. The results of the study show that the village tourism in chocolate has an impact on the economy and society.
\end{abstract}

Keywords: impact, economy, social

\begin{abstract}
Abstrak
Saat ini keberadaan sektor pariwisata menjadi perhatian masyarakat sehingga diberbagai daerah bermunculan tempat-tempat wisata baru. Demikian pula di Blitar saat ini juga banyak dibangun tempat-tempat wisata baru salah satunya adalah wisata kampung coklat. Dengan dibangunnya tempat-tempat wisata tersebut akankah berdampak pada ekonomi dan sosial masyarakat. Penelitian ini bertujuan untuk mendeskripsikan dampak wisata terhadap ekonomi dan social masyarakat. Metode penelitian yang digunakan untuk menjawab permasalahan tersebut adalah menggunakan pendekatan kualitatif deskriptif. Data diperoleh menggunakan observasi dan wawancara, sedangkan analisis data tiga tahapan yaitu reduksi data, display data dan verifikasi. Hasil penelitian menunjukkan bahwa wisata kampung coklat berdampak pada ekonomi dan sosial masyarakat.
\end{abstract}

Kata Kunci: dampak, ekonomi, sosial 


\section{PENDAHULUAN}

Saat ini keberadaan tempat-tempat pariwisata menjamur di mana-mana terlebih saat ini pemerintah telah melaksanakan program otonomi daerah, maka industri pariwisata merupakan salah satu alternatif yang dapat dimanfaatkan sebagai sumber penerimaan daerah (Suwena dan Widyatmaja, 2017). Dalam perkembangannya peranan pariwisata dalam pembangunan akan berdampak pada tiga aspek, yaitu: 1) aspek ekonomi sebagai sumber penerimaan berupa devisa, pajak-pajak, retribusi dan penerimaan lainnya; 2) aspek sosial yang dapat membuka lapangan pekerjaan baru bagi masyarakat dan 3) aspek budaya pariwisata dapat dipergunakan untuk memperkenalkan budaya lokal kepada wisatawan. Hal ini sesuai dengan pendapat Hermawan (2016) yang menyatakan bahwa pariwisata terbukti memberi dampak positif bagi kehidupan ekonomi masyarakat seperti: menciptakan peluang kerja baru, meningkatkan kesempatan berusaha, meningkatkan pendapatan masyarakat lokal, meningkatkan pendapatan daerah melalui retribusi dan pajak dan lain sebagainya.

Blitar merupakan daerah yang memiliki banyak tempat-tempat pariwisata yang sudah terkenal seperti makam Proklamator, wisata edukasi, agrowisata dan lain-lain. Salah satu tempat agrowisata yang tergolong baru dan banyak dikunjungi wisatawan yaitu Wisata Edukasi Kampung Coklat yang berada di Kecamatan Kademangan Kabupaten Blitar. Kampung Coklat merupakan salah satu tempat wisata di Blitar yang diminati oleh banyak wisatawan, karena tempat wisata ini tidak hanya mengandalkan keindahan yang di tawarkan oleh tempat wisata, lebih dari itu tempat wisata ini menekankan pada pendidikan yang di berikan oleh destinasi wisata edukasi ini yaitu seputar hal mengenai tanaman coklat dari sejarahnya hingga penyebarannya sampai ke Indonesia. Dan yang menjadi daya tarik wisatawan berkunjung adalah bahwa tempat wisata ini mengandalkan hasil olahan berbagai macam produk yang berbahan dasar coklat.
Keberhasilan pengelolaan Pariwisata Kampung Coklat dalam mengelola tempat wisata ini menjadikannya salah satu tempat wisata yang banyak diminati para wisatawan. Hal tersebut sangat berdampak positif bagi warga sekitar yang bertempat tinggal diarea sekitar wilayah kampung coklat pada aspek ekonomi, sosial dan budaya. Hasil observasi awal menunjukkan bahwa dengan adanya Pariwisata Kampung Coklat dapat meningkatkan perekonomian dan sosial masyarakat. Berdirinya Pariwisata Kampung Coklat warga masyarakat yang sebelumnya hanya bertani sekarang banyak yang memanfaatkannya dengan membuka usaha atau berdagang, membuka tempat parkir diarea wilayah sekitar kampung coklat, sehingga baik langsung maupun tidak langsung juga akan membuka lapangan kerja. Hal ini sejalan dengan peraturan pemerintah yang tertuang dalam Undang-Undang No. 10 Tahun 2009 tentang kepariwisataan, menyatakan bahwa penyelenggaraan suatu kegiatan pariwisata harus memiliki kemampuan untuk memperluas kesempatan berusaha dan kesempatan kerja, mampu berkontribusi meningkatkan pendapatan nasional dalam rangka meningkatkan kesejahteraan dan kemakmuran rakyat, serta mendorong pendayagunaan produksi nasional.

\section{Pariwisata}

Di tengah-tengah kesibukan dalam beraktivitas untuk mengurangi kepenatan dan kejenuhan banyak masyarakat yang melakukan refreshing dengan berwisata ke tempat-tempat tertentu. Wisata adalah aktivitas perjalanan yang dilakukan oleh seseorang atau sekelompok orang dengan mengunjungi tempat-tempat tertentu untuk tujuan rekreasi, pengembangan pribadi, atau mempelajari keunikan daya tarik wisata yang dikunjungi dalam jangka waktu sementara.

Sesuai dengan Undang-undang Nomor 10 tahun 2009 tentang Kepariwisataan disebutkan pariwisata adalah berbagai macam kegiatan wisata dan didukung berbagai fasilitas serta layanan yang disediakan oleh masyarakat, pengusaha, 
pemerintah dan pemerintah daerah.

\section{Tujuan Pariwisata}

Sesuai dengan Undang-undang Nomor 10 tahun 2009 tentang Kepariwisataan pasal 4 bahwa kepariwisataan bertujuan untuk: a. meningkatkan pertumbuhan ekonomi; $b$. meningkatkan kesejahteraan rakyat; c. menghapus kemiskinan; d. mengatasi pengangguran; e. melestarikan alam, lingkungan, dan sumber daya; f. memajukan kebudayaan; g. mengangkat citra bangsa; $h$. memupuk rasa cinta tanah air; i. memperkukuh jati diri dan kesatuan bangsa; dan j. mempererat persahabatan antarbangsa.

\section{Dampak ekonomi pariwisata}

Dampak Positif Pariwisata pada Perekonomian

1. Foreign Exchange Earnings. Keberadaan tempat wisata tentu akan menimbulkan transaksi, sehingga perekonomian masyarakat lokal akan tumbuh seiring dengan perkembangan tempat wisata itu sendiri di berbagai sektor dalam bisnis.

2. Contributions To Government Revenues. Berdirinya tempat wisata sudah tentu pemerintah akan mendapatkan pemasukan pendapatan berupa pajak, retribusi dan bea cukai dari barang-barang yang diperjualbelikan di tempat wisata.

3. Employment Generation. Keberadaan tempat wisata akan memberikan kontribusi nyata seperti mampu menciptaan peluang kerja, menciptakan usaha-usaha baru yang terkait pariwisata seperti usaha akomodasi, restoran, klub, taxi, dan usaha kerajinan seni souvenir.

4. Infrastructure Development. Dibukanya tempat-tempat wisata akan mendorong pemerintah lokal untuk menyediakan fasilitas umum yang lebih baik untuk kenyamanan wisatawan dan juga masyarakat sekitar.

5. Development of Local Economies. Keberadaan tempat wisata akan mampu untuk berkembangnya ekonomi masyarakat lokal dengan berbagai pekerjaan yang bisa dilakukan dan peluang-peluang usaha.

\section{Dampak sosial pariwisata}

Dibangunnya tempat wisata juga berpengaruh terhadap kehidupan sosial masyarakat, sebagai berikut:

\section{Struktur Sosial}

Pengaruh berdirinya tempat wisata pada struktur sosial adalah a. adanya penambahan kesempatan kerja di sektor pelayanan yang sebelumnya sektor pertanian; b. modernisasi di sektor pertanian dan penjualan hasil panen; c. pemerataan pendapatan masyarakat di daerah tujuan wisata yang akan dikunjungi wisatawan. d. berkurangya perbedaan dalam pendidikan dan kesempatan berusaha atau pekerjaan.

2. Modernisasi Keluarga. a. ibu-ibu yang tadinya hanya sebagai ibu rumah tangga bertambah aktivitasnya sebagai pedagang, pemilik toko, warung makan, atau bekerja pada kerajinan tangan dan karyawan tempat wisata; b. terjadi kelonggaran perlakuan orang tua terhadap anak-anak, dari disiplin ketat menjadi anak yang bebas memilih sesuai dengan yang dicita-citakan.

3. Peningkatan pengetahuan masyarakat. Keberadaan tempat-tempat wisata akan mampu meningkatkan wawasan masyarakat sebagai berikut: a. adanya perubahan tingkah laku ke arah yang lebih baik dalam beretika dan cara berkomu-nikasi; b. dapat menghilangkan prasangka negatif di masyarakat.

\section{METODE PENELITIAN}

Pendekatan dalam penelitian ini ialah menggunakan pendekatan kualitatif dengan maksud untuk mendeskripsikan dampak pariwisata kampung coklat dalam aspek ekonomi dan sosial masyarakat di desa Plosorejo Kecamatan Kademangan Kabupaten Blitar. Lokasi penelitian adalah di Desa Plosorejo di Kecamatan Kademangan Kabupaten Blitar.

Data dalam penelitian ini adalah data primer maupun data sekunder yang diperoleh dari nara sumber yang terdiri dari perangkat desa, pedagang yang membuka usaha di sekitar area wilayah Pariwisata Kampung Coklat yang ada di dan masyarakat desa Plosorejo. Teknik pengumpulan data 
menggunakan teknik observai, dokumentasi dan wawancara mendalam.

Teknik Analisa data dalam penelitian ini yaitu : a) Reduksi data, b) Display data, d) Verifikasi (Milles dan Huberman).

\section{HASIL DAN PEMBAHASAN \\ Tingkat ekonomi Desa Plosorejo Kecamatan Kademangan Kabupaten Blitar}

Perekonomian masyarakat desa Plosorejo sebelum dibukanya wisata edukasi kampung coklat berdiri tidak seperti sekarang. Sebelum adanya wisata kampung coklat mayoritas masyarakat mengandalkan pertanian atau berkebun yang biasanya pendapatannya musimam dan sebagai ibu rumah tangga. Namun dengan adanya pariwisata kampung coklat tingkat perekonomian masyarakat menjadi semakin sejahtera. Karena masyarakat mendapatkan kesempatan untuk memperbaiki taraf hidupnya.

Dibukanya wisata edukasi kampung coklat ini semua narasumber menyatakan dapat membuka lapangan pekerjaan baru seperti menjadi karyawan di tempat wisata kampung coklat, membuka usaha berdagang diarea wisata kampung coklat, membuka lahan parkir untuk pengunjung, membuka usaha memproduksi makanan dan souvenir yang dijual di sekitar wisata kampung coklat. Keberadaan pariwisata kampung coklat didesa Plosorejo juga membawa berkah bagi masyarakat yang memiliki lahan, karena harga sewa lahan yang cukup tinggi untuk penanaman kebun coklat.

\section{Keberadaan Pariwisata Kampung Coklat}

Keberadaan Pariwisata Kampung Coklat di desa Plosorejo Kecamatan Kademangan Kabupaten Blitar terus dikembangkan oleh manajemen. Berdasarkan hasil observasi diketahui berbagai fasilitas penunjang wisata secara terus menerus dikembangkan sehingga wisata kampung coklat ini sangat cocok sebagai tujuan wisata semua golongan usia. Pariwisata kampung coklat merupakan sebuah pariwisata yang sangat unik, karna memiliki daya tarik tinggi dengan mengusung tema coklat.

Di lokasi wisata kampung coklat banyak kios yang menjual sajian makanan atau pun minuman yang berbahan dasar coklat, sehingga tujuan wisata kampung coklat cocok sebagai lokasi bersantai bersama keluarga sambil menikmati hasil olahan coklat yang nikmat. Sebagai penghasil coklat terbesar di provinsi Jawa Timur kualitas dari produk olahan masyarakat yang berbahan dasar coklat dari Plosorejo Kademangan tak perlu lagi diragukan. Selain memproduksi biji coklat berkualitas yang membanggakan lagi berbagai hasil olahan produk berupa makanan maupun minuman dari bahan dasar coklat telah diekspor ke seluruh nusantara hingga mancanegara.

\section{Dampak Pariwisata Kampung Coklat Pada Aspek Ekonomi dan Sosial Masyarakat Desa Plosorejo Kabupaten Blitar}

Berdasarkan hasil analisis data dapat diketahui bahwa keberadaan wisata edukasi kampung coklat berdampak positif terhadap ekonomi dan sosial masyarakat. Adapun dampak ekonomi terhadap masyarakat adalah sebagai berikut: 1) menciptakan lapangan pekerjaan baru. Dengan dibukanya tempat wisata kampung coklat sudah tentu akan membuka lapangan kerja baru bagi masyarakat sekitar. 2) mengurangi angka penggangguran. Terbukanya lapangan kerja baru akan dapat mengurangi jumlah pengangguran di sekitar hal ini dapat diketahui ada sekitar 150 karyawan yang bekerja di tempat wisata ini. 3) meningkatnya pendapatan masyarakat dengan membuka usaha dengan berjualan dan membuka lahan parkir untuk pengunjung. 4) memberikan peluang masyarakat untuk bekerja sebagai karyawan di pariwisata kampung coklat. 5) membuka peluang masyarakat untuk memproduksi aneka makanan dan souvenir yang dipasarkan di area wisata kampung coklat. 6) harga sewa dan harga jual tanah tinggi. Hal ini sudah menjadi biasa terjadi kalau di suatu tempat berdiri tempat-tempat keramaian harga jual maupun sewa tanah melonjak naik begitu pula yang terjadi di 
sekitar wisata kampung coklat. 7) masyarakat sekitar yang menanam coklat harganya cukup tinggi. Keadaan ini memang menjadi harapan pemilik wisata kampung coklat sebagai bahan olahan khas yang dijual di kios-kios menjadikan harga jual coklat akan cenderung tinggi. Sedangkan dampak sosialnya adalah sebagai berikut: 1) perubahan kualitas hidup masyarakat, hal ini sesuai dengan pernyataan masyarakat bahwa dengan berdirinya wisata kampung coklat meningkatnya tingkat kecukupan masyarakat dalam memenuhi kebutuhan ekonominya. 2) Berubahnya pola berpikir masyarakat dalam hal pentingnya pendidikan dengan semakin meningkat seiring dengan meningkatnya ekonomi keluarga. Sedangkan dampak negatif dari keberadaan wisata edukasi kampung coklat berdasarkan hasil penelitian relatif belum ada.

\section{PENUTUP \\ Simpulan}

Berdasarkan hasil pembahasan menunjukkan bahwa tingkat ekonomi dan sosial masyarakat desa Plosorejo Kecamatan Kademangan Kabupaten Blitar setelah adanya pariwisata kampung coklat semakin membaik. Dengan meningkatnya keadaan ekonomi dan sosial akan berdampak positif pada masyarakat desa Plosorejo menjadi lebih sejahtera dalam sosial dan ekonominya.

Dampak keberadaan wisata kampung coklat bagi masyarakat di desa Plosorejo Kecamatan Kademangan Kabupaten Blitar ialah sebagai berikut : 1) Dampak positif: (1) menciptakan lapangan pekerjaan baru. (2) mengurangi angka penggangguran. (3) meningkatnya pendapatan masyarakat dengan membuka usaha dengan berjualan dan membuka lahan parkir untuk pengunjung. (4) memberikan peluang masyarakat untuk bekerja sebagai karyawan dipariwisata kampung coklat. 5) membuka peluang masyarakat untuk memproduksi aneka makanan dan souvenir yang dipasarkan di area wisata kampung coklat. 6) harga jual dan sewa tanah tinggi. 7) masyarakat sekitar yang menanam coklat harganya cukup tinggi. Sedangkan dampak sosialnya adalah 1) perubahan kualitas hidup masyarakat. 2) berubahnya pola berpikir masyarakat menjadi semakin maju.

\section{Saran}

Pemerintah hendaknya segera mengapresiasi terhadap kampung coklat dengan memberikan pelatihan dan keterampilan yang lain bagi warga agar mampu lebih inovatif dan trampil. Pemerintah memberikan bantuan sarana dan parasaran lain untuk penunjang kegiatan di Kampung Coklat.

\section{DAFTAR PUSTAKA}

Hermawan, H. (2016). Dampak Pengembangan Desa Wisata NglanggeranTerhadap Ekonomi Masyarakat Lokal. Jurnal Pariwisata, III(2).

Moleong, Lexy. (2008). Metodologi Penelitian Kualitatif. Bandung: Remaja Rosdakarya.

Suwena, I Ketut dan Widyatmaja, I Gustu Ngurah. (2017). Pengetahuan Dasar Ilmu Pariwisata, Denpasar Bali: Pustaka Larasan dan Fakultas Pariwisata Universitas Udayana Bali.

Undang-Undang No. 10 Tahun 2009 tentang Kepariwisataan 